\title{
Sarocladium brachiariae sp. nov., an endophytic fungus isolated from Brachiaria brizantha
}

\section{Liu XB ${ }^{1}$, Guo $\mathrm{ZK}^{2}$ and Huang $\mathbf{G X}^{1^{*}}$}

\author{
${ }^{1}$ Environment and Plant Protection Institute, Chinese Academy of Tropical Agricultural Sciences (CATAS), Key \\ Laboratory of Integrated Pest Management on Tropical Crops, Ministry of Agriculture, Key Laboratory for \\ Monitoring and Control of Tropical Agricultural Pests, Haikou, Hainan 571101, P. R. China. \\ ${ }^{2}$ Institute of Tropical Bioscience and Biotechnology, Chinese Academy of Tropical Agricultural Sciences (CATAS), \\ Haikou, Hainan 571101, P. R. China.
}

Liu XB, Guo ZK, Huang GX 2017 - Sarocladium brachiariae sp. nov., an endophytic fungus isolated from Brachiaria brizantha. Mycosphere 8(7), 827-834, Doi 10.5943/mycosphere/8/7/2

\begin{abstract}
In a survey on the diversity of endophytic fungi of Brachiaria brizantha, a new species of Sarocladium was isolated and proposed here as Sarocladium brachiariae. According to the LSU and ITS rDNA sequences and culture morphology and micromorphology, the species differed from the species hitherto described in Sarocladium, and is characterized as a new species. The new species can produce hyphal coils and slimy heads. In addition, raised, cottony, moist to slimy colonies on PDA, and adelophialides, branched conidiophores were also useful characters for distinguishing species from other species of Sarocladium.
\end{abstract}

Keywords - Endophytes - Sarocladium - Phylogeny - Taxonomy

\section{Introduction}

Sarocladium was established by Gams and Hawksworth (1976) based on a species described by Sawada in Taiwan, firstly including two fungal pathogens causing sheath rot of rice. Based on a recent molecular phylogenetic study of rDNA sequences, Summerbell et al. (2011) transferred seven species, formerly named Acremonium kiliense, A. strictum, A. zeae, A. bacillisporum, A. bactrocephalum, A. glaucum and A. ochraceum, to the genus. Yeh \& Kirschner (2014) introduced a new species named Sarocladium spinificis. Giraldo et al. (2015) used multilocus phylogenetic inferences combined with phenotypic data, to introduce $S$. bifurcatum, S. gamsii, S. hominis, S. pseudostrictum, S. subulatum and S. summerbellii, and re-allocated A. implicatum and A. terricola to the genus. Sarocladium attenuatum is confirmed as synonym of the type species of the genus, $S$. oryzae.

Sarocladium presently encompasses 18 species (Summerbell et al. 2011, Giraldo et al. 2015). Although Sarocladium species have traditionally been considered as important phytopathogens (Gams and Hawksworth 1976, Ayyadurai et al. 2005), the genus also contains opportunistic human pathogens (Fincher et al. 1991, Perdomo et al. 2011), and other properties of applied value. For example, S. oryzae produces antibiotics (Bills et al. 2004), and S. zeae (Gams \& Sumner, 1971) is considered as a mutualistic endophyte in maize (Wicklow et al. 2008). Endophytic fungi form nonpathogenic and intercellular associations with host, completing their entire life cycle in the plant 
(Kelemu et al. 2001). Species of the genus Sarocladium are commonly associated with members of Poaceae (Yeh \& Kirschner 2014, Giraldo et al. 2015). Some endophytic fungi are potential biological control agents for plant pathogens (Kelemu et al. 2001). Endophytic-infected plants also possess other properties such as growth stimulation, improved survival, and drought tolerance (Lim et al. 2000, Yang et al. 2014). Brachiaria are commercially important forage grasses in tropical area. In this study, we collected endophytic fungi associated with Brachiaria spp. in China, and a species was identified as a member of Sarocladium, but was not identical to any of the previously described species.

\section{Materials \& Methods}

\section{Plant tissue staining, fungal isolations, and culture maintenance}

In 2005, healthy grass leaves and sheaths of Brachiaria brizantha were collected from Danzhou, China. Plant tissue staining and endophytic fungal isolation were conducted according to the method described by Kelemu et al. (2001). Samples which appeared to have intercellularly growing hyphae were noted, and plants from which the samples originated were used for further fungal isolation. Small pieces $(5 \mathrm{~mm})$ of tissues that surface sterilized were plated on potatodextrose agar, and incubated for 4 to 6 weeks at $28^{\circ} \mathrm{C}$. Cultures were effectively maintained either on PDA supplemented with $10 \mu \mathrm{g} / \mathrm{mL}$ tetracycline, or, for long-term storage, by lyophilization according to the method described by Kelemu et al. (2001).

\section{DNA extraction, amplification and sequencing}

Isolates grow on PDA for 10 days at $25^{\circ} \mathrm{C}$. Genomic DNA was extracted using Genomic DNA Spin Kit (Plant), according to the modified manufacturer's protocol (TIANGEN Co., Ltd., China). The internal transcribed spacer regions and intervening 5.8S nrRNA gene (ITS) and D1/D2 domains of the large-subunit nrRNA were amplified with the primer pairs ITS1/ITS4 and NL1/NL4b, respectively (White et al. 1990, O'Donnell 1993). The PCR products were visualised on an electrophoresis gel after GoldView (Solarbio, China) staining. PCR products of the expected size were purified with E.Z.N.A. ${ }^{\text {TM }}$ Gel Extraction Kit I (OMEGA) according to the manufacturer's instructions. DNA sequencing was done by BGI Biotech (Shenzhen, China) with 3730 DNA Analyzer (Applied Biosystems).

\section{Alignment and phylogenetic analysis}

DNA Sequences were assembled and edited using SeqMan II software (DNAStar, Inc., Madison, Wis.). Related DNA sequences of ITS and LSU rDNA were compared using the BLAST function of GenBank. For phylogenetic analysis, sequences retrieved from the BLAST search and the taxon sampling based on ITS and LSU rDNA sequences (Yeh \& Kirschner 2014, Giraldo et al. 2015) were used (Table1). In addition to sequences of Sarocladium spp., Acremonium species closely related with Sarocladium spp., but outside the Sarocladium clade, were included as outgroup (Giraldo et al. 2012). Multiple sequence alignments were performed with Clustal W using MEGA 5 (Tamura et al. 2011) and manually corrected where necessary. Nucleotide substitution models were generated using MrModeltest v. 2.3 (Nylander et al. 2008). A maximum likelihood phylogenetic analysis of the dataset was performed with PAUP v.4.0b10 (Swofford 2002). Markov Chain Monte Carlo (MCMC) sampling was used to reconstruct phylogenies in Mrbayes v. 3.2 (Ronquist \& Huelsenbeck 2003). Analyses of 2 MCMC chains based on the full dataset were run for $1 \times 10^{7}$ generations and sampled every 100 generations. The alignments and trees in TreeBASE (http://purl.org/phylo/treebase/phylows/study/TB2:S20969?x-accesscode $=\mathrm{e} 79 \mathrm{cef} 78 \mathrm{c} 47 \mathrm{c} 3 \mathrm{~d} 70 \mathrm{ebcb}$ 7314c8a991ab\&format=html), and taxonomic novelties in MycoBank (Crous et al. 2004). 


\section{Phenotypic studies}

Morphological characterization of the fungal isolates was carried out based on cultures grown on potato dextrose agar (PDA), oatmeal agar (OA; filtered oat flakes after $1 \mathrm{~h}$ of simmering $30 \mathrm{~g}$, agar $20 \mathrm{~g}$, distilled water to final volume of $1000 \mathrm{~mL}$ ) and malt extract agar (malt extract 20 $\mathrm{g}$, peptone $1 \mathrm{~g}$, glucose $20 \mathrm{~g}$, agar $15 \mathrm{~g}, \mathrm{H}_{2} \mathrm{O} 1000 \mathrm{ml}$ ). Cultures were incubated at $25 \pm 1{ }^{\circ} \mathrm{C}$ in the dark and periodically examined each 7 days up to 4 weeks. Colony diameters were measured after 14 days of growth, and colony colours determined using the colour charts of Kornerup \& Wanscher (1978). In addition, the ability of the isolates to grow at 15, 20, 25, 30, 35, 37 and $40{ }^{\circ} \mathrm{C}$ was determined on PDA. Conidiophore morphology was observed on cultures grown on dilute malt agar (malt extract $5 \mathrm{~g}, 12 \mathrm{~g}$ agar, $1000 \mathrm{ml}$ distilled $\mathrm{H}_{2} \mathrm{O}$ ) supported on microscope coverslips, other microscopic features were examined and measured by slide cultures on OA, using an Ni-E light microscope (Nikon Corporation, Japan). Photomicrographs were made with a Nikon DS-Ri1 light microscope (Nikon Corporation, Japan). Scanning electron microscope (SEM) micrographs were obtained with a S-3000N scanning electron microscope (Hitachi, Japan).

\section{Results}

\section{Phylogenetic analysis}

The BLAST query revealed that the isolate was shown to be closely related to Sarocladium on the basis of its D1/D2 and the ITS regions. Sequences of the D1/D2 (889 bp) and ITS (585 bp) were deposited in GenBank as KP715271 and EU880834, respectively. When comparing the BLAST search results among sequences exceeding a length of $831 \mathrm{bp}$ of D1/D2 fragments, the highest similarity between our isolate and other identified Sarocladium species was 99\%, namely with one strain of Sarocladium oryzae (GenBank number HG965047, Giraldo et al. 2015). The highest similarity of ITS rDNA fragments was 95\%, namely with one strain of Sarocladium kiliense (Genbank number LN864540, Asadzadeh 2015). The systematic positions of Sarocladium sp. was estimated by the combined analysis from ITS and D1/D2 partial gene consisted of 980 characters including alignment gaps. The phylogenetic analysis allowed distributing the isolates included in this study into 18 lineages (Fig. 1). These lineages were phylogenetically distant enough to be considered as different species.

\section{Taxonomy}

On the basis of phylogenetic analysis and phenotypic features, we propose that the isolated fungus Sarocladium sp. is different from any previously described species in this genus and therefore are proposed as new.

Sarocladium brachiariae X.B. Liu, G.X. Huang \& Z.K Guo sp. nov.

Fig. 2A-K

MycoBank number: MB 814539, Facesoffungi number: FoF 03372

Etymology - Referring to the host (Brachiaria brizantha). 
Table1 Species and strains included in the study, their origin and GenBank accession numbers.

\begin{tabular}{|c|c|c|c|c|c|}
\hline \multirow[b]{2}{*}{ Species } & \multirow[b]{2}{*}{ Strain } & \multirow[b]{2}{*}{ Source } & \multicolumn{2}{|c|}{ GenBank accession no. } & \multirow[b]{2}{*}{ References } \\
\hline & & & $\begin{array}{l}\mathrm{D} 1 / \mathrm{D} 2 \\
\text { domains of } \\
\text { 28SrRNA gene }\end{array}$ & ITS region & \\
\hline Sarocladium bacillisporum & CBS $425.67^{\mathrm{T}}$ & Soil,Ontario, Canada & HE608658 & HE608639 & Giraldo et al. 2015 \\
\hline Sarocladium bactrocephalum & CBS $749.69^{\mathrm{T}}$ & Ustilago sp., Canada & HQ231994 & HG965006 & Giraldo et al. 2015 \\
\hline Sarocladium bifurcatum & UTHSC05-3311 ${ }^{\mathrm{T}}$ & Bronchoalveolar lavage fluid, USA & HG965057 & HG965009 & Giraldo et al. 2015 \\
\hline Sarocladium gamsii & CBS $707.73^{\mathrm{T}}$ & Dead stem of Pandanus lerum, Sri Lanka & HG965063 & HG965015 & Giraldo et al. 2015 \\
\hline Sarocladium glaucum & CBS $796.69^{\mathrm{T}}$ & Woolen overcoat, Solomon Islands & HE608657 & FN691454 & Giraldo et al. 2015 \\
\hline Sarocladium hominis & UTHSC04-1034 & Right calf tissue, USA & HG965060 & HG965012 & Giraldo et al. 2015 \\
\hline Sarocladium implicatum & CBS $959.72^{\mathrm{NT}}$ & Desert soil, Egypt & HG965072 & HG965023 & Giraldo et al. 2015 \\
\hline Sarocladium kiliense & CBS $122.29^{\mathrm{T}}$ & Skin, Germany & HQ232052 & FN691446 & Giraldo et al. 2015 \\
\hline Sarocladium mycophilum & CBS $166.92^{\mathrm{T}}$ & Cortinarius subsertipes, Germany & HG965046 & HG965024 & Giraldo et al. 2015 \\
\hline Sarocladium ochraceum & CBS $428.67^{\mathrm{T}}$ & Zea mays, Kenya & HQ232070 & HG965025 & Giraldo et al. 2015 \\
\hline Sarocladium oryzae & CBS $180.74^{\mathrm{ET}}$ & Oryza sativa, India & HG965047 & HG965026 & Giraldo et al. 2015 \\
\hline Sarocladium oryzae & CBS 399.73 & Oryza sativa, India & HG965048 & HG965027 & Giraldo et al. 2015 \\
\hline Sarocladium oryzae & CBS 414.81 & Oryza sativa, Nigeria & HG965049 & HG965028 & Giraldo et al. 2015 \\
\hline Sarocladium pseudostrictum & UTHSC $02-1892^{\mathrm{T}}$ & Sputum, USA & HG965073 & HG965029 & Giraldo et al. 2015 \\
\hline Sarocladium strictum & CBS $346.70^{\mathrm{T}}$ & Triticum aestivum, Germany & HQ232141 & FN691453 & Giraldo et al. 2015 \\
\hline Sarocladium subulatum & MUCL9939T & Soil, Egypt & HG965075 & HG965031 & Giraldo et al. 2015 \\
\hline Sarocladium summerbellii & CBS $430.70^{\mathrm{T}}$ & Soil from greenhouse, The Netherlands & HG965078 & HG965034 & Giraldo et al. 2015 \\
\hline Sarocladium terricola & CBS $243.59^{\mathrm{T}}$ & Forest soil, USA & HE608659 & FN706553 & Giraldo et al. 2015 \\
\hline Sarocladium zeae & CBS $800.69^{\mathrm{T}}$ & Zea mays stalk, USA & HQ232152 & FN691451 & Giraldo et al. 2015 \\
\hline Sarocladium spinificis & Z0106 Ex-type & Root of Spinifex littoreus, Taiwan & JQ954463 & KF269096 & $\begin{array}{l}\text { Yeh \& Kirschner } \\
2014\end{array}$ \\
\hline $\begin{array}{l}\text { Sarocladium sp. ( = Sarocladium } \\
\text { brachiariae) }\end{array}$ & CGMCC $2192^{\mathrm{T}}$ & Leaves of Brachiaria brizantha, China & KP715271 & EU880834 & This study \\
\hline Acremonium curvulum & CBS $430.66^{\mathrm{T}}$ & Wheat field soil, Germany & HE608656 & HE608638 & Giraldo et al. 2012 \\
\hline
\end{tabular}

Note: ${ }^{\mathrm{ET}}=$ Epitype strain; ${ }^{\mathrm{NT}}=$ Neotype strain $;{ }^{\mathrm{T}}=$ type strain 


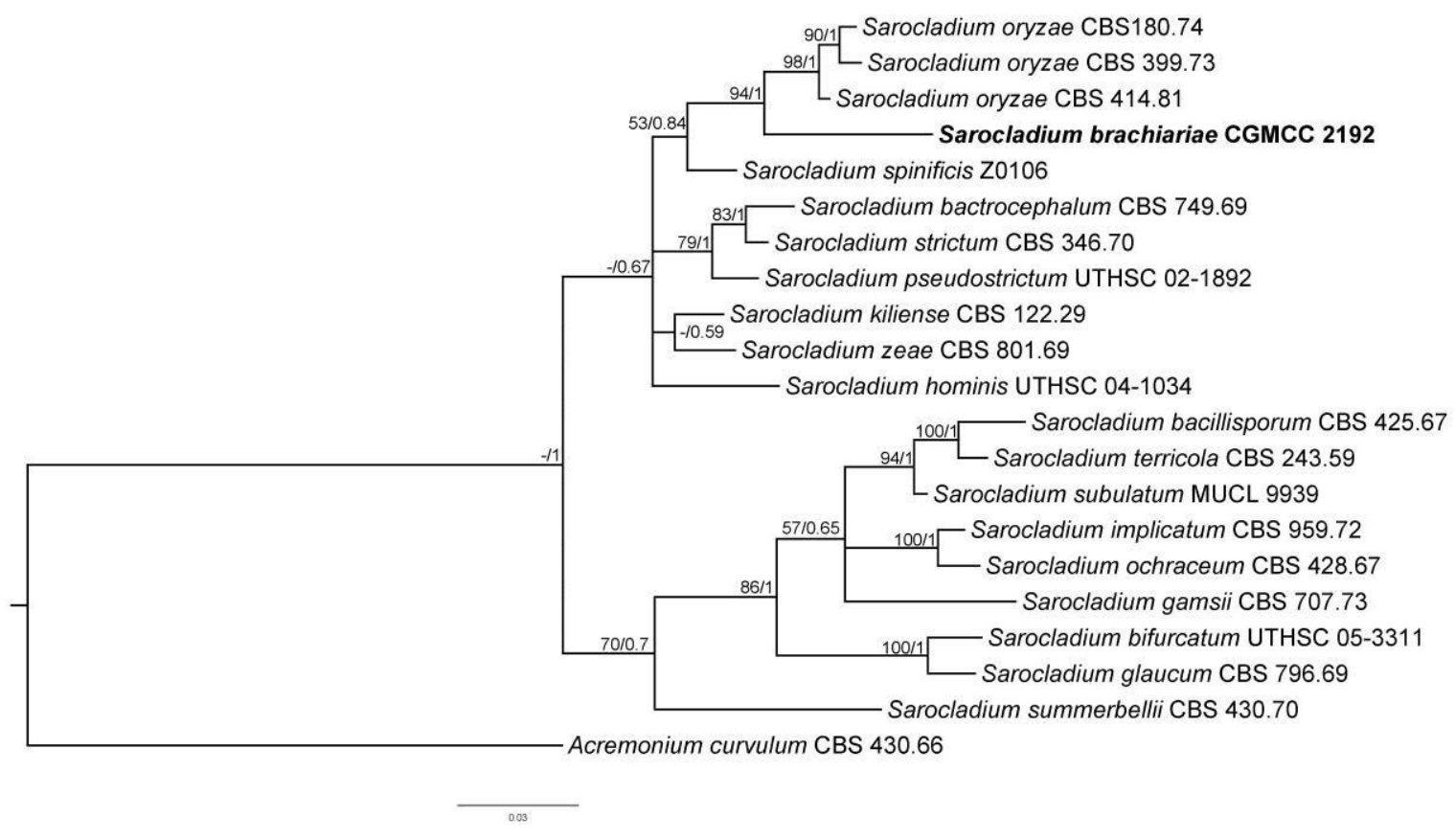

Fig. 1 Maximum-likelihood (ML) tree and Bayesian analysis obtained from the combined DNA sequence data from two loci (D1/D2 and ITS). Bootstrap support values above $50 \%$ and Bayesian posterior values above 0.5 are shown at each node (ML/PP) are shown at the nodes; Acremonium curvulum is used as outgroup.
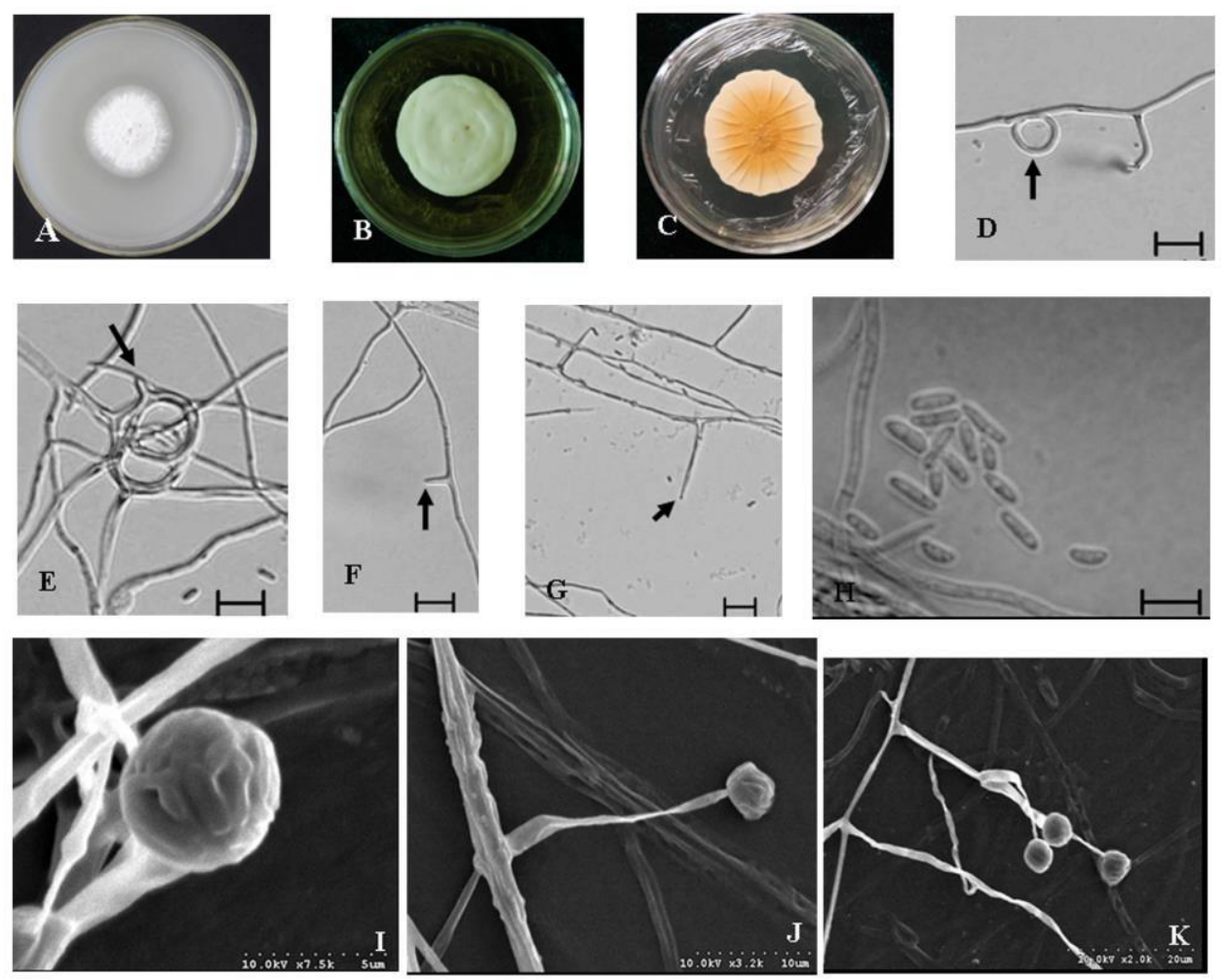

Fig. 2 Sarocladium brachiariae $\left(\mathrm{CGMCC} 2192^{\mathrm{T}}\right)$. A. Colonies on OA after 14 days at $25 \mathrm{C}$; B, C. colonies on PDA after 14 days at 25 C; D. Hyphal coil (arrow); E. Adelophialides in a hyphal coil (arrow); F. adelophialides (arrow); G. phialide with distinct periclinal thickening at the apex (arrow); H. conidia; I. conidia arranged in slimy heads; J, K. simple and branched conidiophores with conidia arranged in slimy heads. - Scale bars: $\mathrm{D}-\mathrm{H}=10 \mu \mathrm{m}$. 
Type - HND5, CGMCC 2192.

Colonies on $\mathrm{OA}$ at $25^{\circ} \mathrm{C}$ attaining $30-35 \mathrm{~mm}$ in 14 days, white, flat, powdery. On PDA attaining $30-37 \mathrm{~mm}$ at $25^{\circ} \mathrm{C}$ after 14 days in the dark, white to yellowish white, raised, cottony, moist to slimy, reverse pale orange, sometime radially folded. Vegetative hyphae septate, hyaline, smooth- and thin-walled, 1-2 $\mu \mathrm{m}$ wide, sometimes bound together into ropes, could produce hyphal coil and net form structure. Conidiophores erect, arising directly from vegetative hyphae, simple or poorly branched, hyaline to subhyaline. Phialides straight or slightly flexuous, subulate, 14-30 (40) $\mu \mathrm{m}$ long, 2-2.5 $\mu \mathrm{m}$ wide at the base, with a distinct periclinal thickening at the conidiogenous locus, hyaline, thin- and smooth-walled; adelophialides present on OA, $2-8 \mu \mathrm{m}$ long, $1.5 \mu \mathrm{m}$ wide at the base. Conidia unicellular, cylindrical with rounded ends, 3-8 $(-11) \times 1-1.5 \mu \mathrm{m}$, hyaline to subhyaline, thin- and smooth-walled, arranged in slimy heads. Chlamydospores and sexual morph not observed.

Material examined - CHINA. Hainan province: Danzhou, Chinese Academy of Tropical Agricultural, on leaves of Brachiaria brizantha, 10 September 2005, X.B Liu, HND5 (CGMCC 2192, type).

\section{Discussion}

Sarocladium is a hyphomycetous genus belonging in the family Hypocreaceae, order Hypocreales and class Sordariomycetes (Maharachchikumbura et al. 2015, 2016) and has been well-studied by various authors (Summerbell et al. 2011, Yeh \& Kirschner 2014, Giraldo et al. 2015) Based on the combination of a multilocus analysis and phenotypic features, we propose and describe a new species of Sarocladium, S. brachiariae. Apart from DNA sequence differences, the species is proposed as new because of raised, cottony and moist to slimy colonies on PDA, and branching conidiophore, adelophialides, cylindrical conidia arranged in slimy heads. Key morphological feature of the fungi is the production of hyphal coil. Giraldo et al. (2015) showed that all the Sarocladium species producing cylindrical conidia arranged in slimy heads, grouped in the same lineage, while those species with fusiform conidia arranged in chains, or/and slimy heads were distributed in other clades. This distribution is in agreement with our study. Sarocladium brachiariae together with $S$. strictum, S. hominis, S. pseudostrictum, S. bactrocephalum, S. kiliense, $S$. spinificis, $S$. oryzae and $S$. zeae formed a clade morphologically characterized by cylindrical or ellipsoidal conidia arranged in slimy heads.

Sarocladium brachiariae can be differentiated from S. hominis, S. pseudostrictum, S. bactrocephalum and $S$. zeae by its faster growth rate on OA and PDA at $25 \mathrm{C}$, its ability to grow at 37 C, and its adelophialides (Giraldo et al. 2015); Sarocladium kiliense differs in the formation of chlamydospores and appears as dirty orange to pale ochraceous colonies on OA (Summerbell et al. 2011); S. spinificis differs from S. brachiariae in the absent of branched conidiophores and having longer conidia (Yeh \& Kirschner 2014); S. brachiariae nests in a well-supported clade together with $S$. oryzae, but can be differentiated in the following features: $S$. oryzae produces repeatedly branched conidiophores and colonies with a dull buff grey to dull bluish green reverse on PDA (Bills et al. 2004). S. brachiariae is morphologically very similar with $S$. strictum, such as raised, cottony and moist to slimy colonies on PDA, hyphae bound together into ropes, branched conidiophores, adelophialides, conidia, and able to grow at $37 \mathrm{C}$, but $S$. brachiariae can produce hyphal coils, which is specific to this species.

Traditionally, species of Sarocladium have been reported as plant pathogens or as saprobes (Gams \& Hawksworth 1976, Chen et al. 1986). However, numerous studies have demonstrated that some also be involved in endophyte of plant, which displayed significant antifungal activity against plant pathogenic fungi (McGee et al. 1991, Kelemu et al. 2001, Wicklow et al. 2005, Summerbell et al. 2011, Yeh \& Kirschner 2014). Surprisingly, the new species prominently shows broad-spectrum inhibition to growth of many tested plant pathogenic fungi on solid media plate, including Colletotrichum gloeosporioides of mango trees, Fusarium oxysporium f.sp. cubense, Gloeosporium musarum, Colletotrichum gloeosporioides of rubber trees, Corynespora cassicola of 
papaya, Fusarium oxysporium of bamboo, Magnaporthe grisea, Bipolaris oryzae Shoem, Colletotrichum falcatum Went and Drechslera sp. (data no shown).

\section{Acknowledgements}

This study was supported by the National Natural Science Foundation of China (grant no.41406083)

\section{References}

Asadzadeh M, Ahmad S, Hagen F, et al. 2015 - Simple, Low-Cost Detection of Candida parapsilosis Complex Isolates and Molecular Fingerprinting of Candida orthopsilosis Strains in Kuwait by ITS Region Sequencing and Amplified Fragment Length Polymorphism Analysis. Plos One, 10(11), e0142880.

Ayyadurai N, Kirubakaran S, Srisha S, Sakthivel N. 2005 - Biological and molecular variability of Sarocladium oryzae, the sheath rot pathogen of rice (Oryza sativa L.). Current Microbiology 50, 319-323.

Bills GF, Platas G, Gams W. 2004 - Conspecificity of the cerulenin and helvolic acid producing 'Cephalosporium caerulens', and the hypocrealean fungus Sarocladium oryzae. Mycological Research 108, 1291-1300.

Chen JD, Zhang GC, Fu XH. 1986 - The pathogen of rice purple sheath disease Sarocladium synense sp. nov. Acta Mycologica Sinica Supplement 1, 318-327.

Crous PW, Gams W, Stalpers JA, Robert V, Stegehuis G. 2004 - MycoBank: an online initiative to launch mycology into the 21st century. Studies in Mycology 50, 19-22.

Fincher RM, Fisher JF, Lovell RD, Newman CL, Espinel-Ingroff A.1991 - Infection due to the fungus Acremonium (Cephalosporium). Medicine 70, 398-409.

Gams W, Sumner DR. 1971 - Cephalosporium-artige Schimmelpilze (Hyphomycetes). Gustav Fischer Verlag, Stuttgart, 121.

Gams W, Hawksworth DL. 1976 ['1975'] - The identity of Acrocylindrium oryzae Sawada and a similar fungus causing sheath rot of rice. Kavaka 3, 57-61.

Giraldo A, Gené J, Cano J, De Hoog S, Guarro J. 2012 - Two new species of Acremonium from Spanish soils. Mycologia 104, 1456-1465.

Giraldo A, Gené J, Sutton DA, Madrid H, de Hoog GS, Cano J, Decock C, Crous PW, Guarro J. 2015 - Phylogeny of Sarocladium (Hypocreales). Persoonia 34, 10-24.

Kelemu S, White JF Jr., Muñoz F, Takayama Y. 2001 - An endophyte of the tropical forage grass Brachiaria brizantha: Isolating, identifying, and characterizing the fungus, and determining its antimycotic properties. Canadian Journal of Microbiology 47, 55-62.

Kornerup A, Wanscher JH. 1978 - Methuen handbook of colours. 3rd edition. London, Eyre Methuen.

Lim HB, Chung YJ, Bae JY, Kim DJ, Kwon HJ, et al. 2000 - Plant growth-promoting activity Acremonium strictum MJN1 Isolated from Root of Panax ginseng. Agricultural Chemistry \& Biotechnology 43, 104-108.

Maharachchikumbura SSN, Hyde KD, Gareth Jones EB, et al. 2015 - Towards a natural classification and backbone tree for Sordariomycetes. Fungal Diversity 72, 199-301

Maharachchikumbura SSN, Hyde KD, Gareth Jones EB et al. 2016 - Families of Sordariomycetes. Fungal Diversity Published online: 03 June.

McGee PA, Hincksman MA, White CS.1991 - Inhibition of Growth of Fungi Isolated from Plants by Acvemonium stvictum. Australian Journal of Agricultural Research 42, 1187-1193.

Nylander JAA, Wilgenbusch JC, Warren DL, Swofford DL. 2008 - AWTY (are we there yet?): a system for graphical exploration of MCMC convergence in Bayesian phylogenetics. Bioinformatics 24, 581-583. 
O’Donnell K. 1993 - Fusarium and its near relatives. In: Reynolds R, Taylor JW (eds) The fungal holomorph: mitotic, meiotic and pleomorphic speciation in fungal systematics. CBA International, Wallingford, 225-233.

Perdomo H, Sutton DA, García D, Fothergill AW, Cano J, Gené J, Summerbell RC, Rinaldi MG, Guarro J. 2011 - Spectrum of clinically relevant Acremonium species in the United States. Journal of Clinical Microbiology 49, 243-256.

Ronquist, F, Huelsenbeck, JP. 2003 - MrBayes 3: Bayesian phylogenetic inference under mixed models. Bioinformatics 19, 1572-1574.

Summerbell RC, Gueidan C, Schroers HJ, de Hoog GS, Starink M, Arocha Rosete Y, Guarro J and Scott JA. 2011 - Acremonium phylogenetic overview and revision of Gliomastix, Trichothecium and Sarocladium. Studies in Mycology 68, 139-162.

Swofford DL 2002 - PAUP*. Phylogenetic analysis using parsimony (* and other methods). version 4.0b10. Computer programme. Sinauer Associates, Sunderland

Tamura K, Peterson D, Peterson N, et al. 2011 - MEGA5: molecular evolutionary genetics analysis using maximum likelihood, evolutionary distance, and maximum parsimony methods. Molecular Biology and Evolution 28, 2731-2739.

White TJ, Bruns T, Lee J, et al. 1990 - Amplification and direct sequencing of fungal ribosomal RNA genes for phylogenetics. In: Innis MA, Gelfand DH, Sninsky JJ, et al. (eds), PCR protocols: a guide to methods and applications. Academic Press, New York 38, 315-322.

Wicklow DT, Roth S, Deyrup ST, Gloer JB. 2005 - A protective endophyte of maize:

Acremonium zeae antibiotics inhibitory to Aspergillus flavus and Fusarium verticillioides. Mycological Research 109, 610-618

Wicklow DT, Poling SM, Summerbell RC. 2008 - Occurrence of pyrrocidine and dihydroresorcylide production among Acremonium zeae populations from maize grown in different regions. Canadian Journal of Plant Pathology 30, 425-433.

Yang T, Ma S, Dai CC. 2014 - Drought degree constrains the beneficial effects of a fungal endophyte on Atractylodes lancea. Journal of Applied Microbiology 117, 1435-1449.

Yeh YH, Kirschner R. 2014 - Sarocladium spinificis, a new endophytic species from the coastal grass Spinifex littoreus in Taiwan. Botanical Studies 55, 25. 